\title{
Preparation of Large Area Anodic Alumina Membranes and their Application to Thin Film Fuel Cell
}

\author{
Bocchetta $\mathrm{P}^{1}$, Santamaria $\mathrm{M}^{\star 2}$ and Di Quarto $\mathrm{F}^{2}$ \\ ${ }^{1}$ Dipartimento di Ingegneria dell'Innovazione, Università del Salento, Italy \\ ${ }^{2}$ Electrochemical Material Science Laboratory, Facoltà di Ingegneria, Università di Palermo, Italy
}

*Corresponding author: Santamaria M, Electrochemical Material Science Laboratory, Facoltà di Ingegneria, Università di Palermo, Viale delle Scienze, Ed. 6, 90128 Palermo, Italy, E-mail: monica.santamaria@unipa.it

Citation: Bocchetta P, Santamaria M, Di Quarto F (2014) Preparation of Large Area Anodic Alumina Membranes and their Application to Thin Film Fuel Cell. J Mater Sci Nanotechnol 1(1): S104. doi: 10.15744/2348-9812.1.S104

Received Date: May 14, 2014 Accepted Date: July 02, 2014 Published Date: July 04, 2014

\begin{abstract}
The design of an electrochemical reactor for the preparation of self-supported comparatively thin (up to $10 \mu \mathrm{m}$ ) and large area (up to $50 \mathrm{~cm}^{2}$ ) anodic alumina membranes is described allowing growth of porous alumina at high applied potential (up to $150 \mathrm{~V}$ ) without burning. Residual $\mathrm{Al}$ and barrier oxide beneath the porous film are dissolved through a vessel equipped with a gaskets system, which allows to expose to the dissolving solution an $\mathrm{Al}$ area lower than the anodised surface on the front leading to self-supported alumina membranes. According to scanning electron microscopy inspection and $\mathrm{Hg}$-porosity measurements, the anodizing cell and conditions lead to the production of 25 and $50 \mathrm{~cm}^{2} \mathrm{Al}_{2} \mathrm{O}_{3}$ porous layers with structural and morphological features very similar to those shown by commercial membranes (pore diameters $200 \mathrm{~nm}$ and pore densities 1012 pores $/ \mathrm{m}^{2}$ ). The application of such large area membranes as support of inorganic proton conductors in thin film fuel cell proves their performance scalability.
\end{abstract}

\section{Introduction}

In the last decade, a significant amount of literature has been produced on the template-assisted synthesis of nanostructures (metals, oxides and semiconductors) with various morphologies (tubes, wires, rods) using commercial anodisk porous alumina membranes by electrodeposition [1-5], sol-gel [6-8] and wet impregnation [9,10]. This latter technique allowed to use AAMs as support of mechanically poor proton conductors for application in thin film $(<50 \mu \mathrm{m}) \mathrm{H}_{2} / \mathrm{O}_{2}$ fuel cell at intermediate [9] and low temperatures [10-12] using commercial membranes (Anodisc-47 Whatman, pore diameters $0,2 \mu \mathrm{m}$, thickness $\sim 50 \mu \mathrm{m}$ ) filled with different proton conductors.

However, owing to the limitation of the areas (disc diameter $\Phi=2-4 \mathrm{~cm}$ ), the shape (disks) and the mechanical robustness (resulting from the limited thickness and brittle character), the commercial anodic alumina membranes are not suitable for devices, where large area, highly flexible and easy handle thin film porous alumina are required. In the literature several papers appeared on the influence of the anodization parameters, aluminium surface treatments and barrier layer etching on the preparation of anodic alumina membranes [13-26], but little concerns the specifics of the electrochemical cell design used to anodize aluminium. If we consider also that the most experimental difficulties in the growth of porous layer is represented by the delimitation of the electrodic area, a detailed explanation of a process able to produce self-supported Anodic Alumina Membranes (AAM) seems really useful in helping the applicative research. In this work we designed an electrochemical reactor, composed by a gaskets system able to perfectly insulate the aluminium surface exposed to the solution up to high anodization voltages (150 V) without incurring in burning. The performance of the cell has been studied and optimised for the production of AAMs with area up to 50 $\mathrm{cm}^{2}$ using phosphoric acid as electrolyte. The post-anodization treatments of the aluminium/porous oxide electrodes (aluminium removal and chemical etching) are designed in order to obtain highly handable thin film membranes with a residual metal border opportunely left around the anodised surface. This method successfully produces self-supported large area AAMs with an easy manipulation with thickness down to $10 \mu \mathrm{m}$. After impregnation with $\mathrm{CsH}_{2} \mathrm{PO}_{4}$ or $\mathrm{Cs} 0.86\left(\mathrm{NH}_{4}\right) 1.14 \mathrm{SO}_{4} \mathrm{Te}(\mathrm{OH})_{6}(\mathrm{CsNST}), 25 \mathrm{~cm}^{2}$ home-made AAMs have been tested in single module $\mathrm{H}_{2} / \mathrm{O}_{2}$ fuel cell comparing the obtained performances with those obtained using commercial membranes.

\section{Experimental}

\section{Preparation of AAM membranes}

The aluminium electrodes were cut from $100 \mu \mathrm{m}$ thick aluminium foils (purity: 99.99\%) supplied by Becromal S.p.A.- Milano. Prior to anodising, the samples were degreased by ultrasonic rinsing in acetone and in water for 5 min. A square area of either 25 and $50 \mathrm{~cm}^{2}$ was exposed to the electrolytic solution in a thermally insulated bath, whose temperature was controlled within $\pm 1{ }^{\circ} \mathrm{C}$ 
by means of a Lauda refrigerator (mod RE 106). Vigorous stirring was maintained during anodising in order to get an uniform temperature on the electrode surface. Anodization was carried out in 0.4 and $0.1 \mathrm{M} \mathrm{H}_{3} \mathrm{PO}_{4}$ aqueous solutions using a linear potential scan of $0.2 \mathrm{~V} \mathrm{~s}^{-1}$ up to the final value which was held for different circulated charges in order to grow porous layers of different thickness. Aluminium foils were used as cathode in order to make the setup much less expensive. A Glassman high tension power source (series ER) was used in a two-electrode configuration cell. After anodising, the cell was disassembled and each sample was washed thoroughly with distilled water and dried in air. The detachment of anodic oxide layer was performed by selective chemical dissolution in $0.1 \mathrm{M} \mathrm{CuCl}_{2}+20 \% \mathrm{w} / \mathrm{w} \mathrm{HCl}$ solution at $5{ }^{\circ} \mathrm{C}$. The opening of the pores on the barrier layer side was achieved by chemical etching of porous oxide in acidic or basic solutions.

Scanning Electron Microscopy analysis was performed by using a Philips XL30 ESEM coupled with Energy Dispersive X-ray spectroscopy equipment. Porosity measurements were conducted with a Hg-porosimetry Thermo electron corporation $140 / 240$ series.

\section{Fuel cell tests}

The home-prepared AAMs were filled with $\mathrm{CsH}_{2} \mathrm{PO}_{4}$ proton conductor by simple impregnation in saturated $\mathrm{CsH}_{2} \mathrm{PO}_{4}$ or $\mathrm{CsNST}_{5}$ aqueous solution and drying in air for $1 \mathrm{~h}[10,12]$. The composite membranes prepared were sandwiched between two carbon paper electrodes (Toray 40\% wet Proofed-E-Tek), covered with a mixture Pt black/C black (30 \% Pt on Vulcan XC-72, E-Tek)/ CsNST wt $15 \%$, stirred in n-butyl acetate for at least 3 hours. The catalyst loading was $1 \mathrm{mg} \mathrm{cm}^{-2}$ of black platinum. The active area was delimited by insulating silicone rubber having an area of 10 or $25 \mathrm{~cm}^{2}$. The membrane electrode assembly was then assembled in a single fuel cell apparatus (FuelCellTechnologies, Inc.) and fed with oxygen ( $99.5 \%$ purity, 1 bar), and hydrogen (99.5\% purity, 1 bar) humidified at room temperature. Polarization curves were acquired by using a h-tec Fuel Cell Monitor (item 1950).

\section{Results and Discussions}

\section{Cell Design and anodization parameters}

A batch electrochemical reactor for the preparation of self-supported comparatively thin (up to $10 \mu \mathrm{m})$ and large area $\left(25-50 \mathrm{~cm}^{2}\right.$ ) AAMs has been designed and realized (Figure 1). Two electrodes can be anodized in parallel. The aluminium electrode is exposed to the solution through a window, which guarantees the perfect sealing of the metal by means of silicone gaskets fixed on the metal surface by six screws. The symmetry of the electrodes in the cell has been designed to allow an easy heat distribution, thus even if two anodic windows are present simultaneously the circulation of the electrolyte (stirring) and the cooling serpentine guarantee an efficient temperature control. The planar geometry of the gaskets permits the regular growth of porous alumina also in proximity of the borders where the strong internal mechanical tensions of the growing oxide often cause breakdown phenomena.

(a)

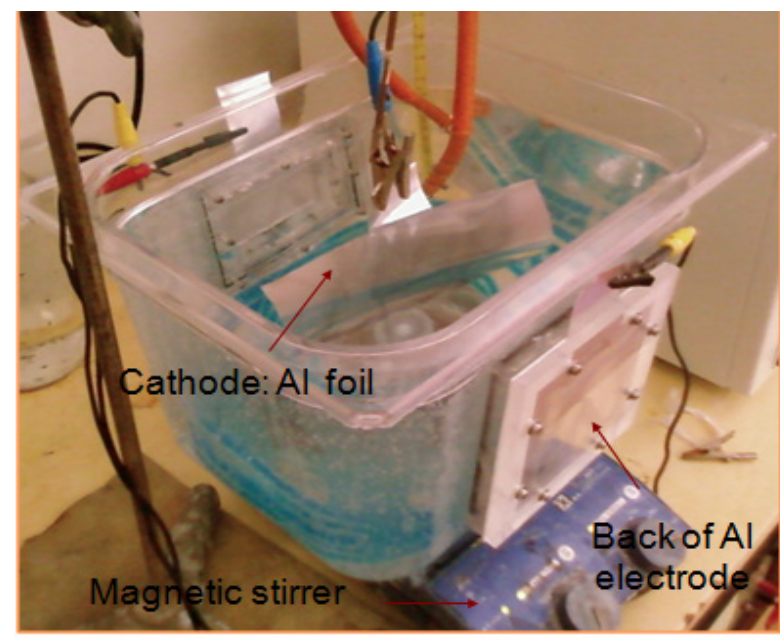

(b)

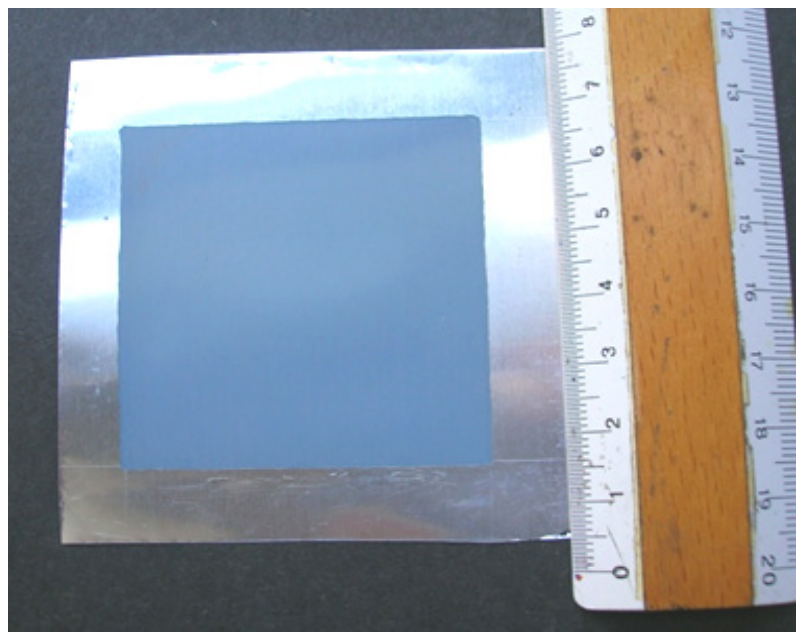

Figure 1: (a) Photo of the electrochemical batch reactor realized in our laboratory for the fabrication of large area $\left(50 \mathrm{~cm}^{2}\right) \mathrm{AAMs}$. (b) Appearance of Al-supported $25 \mathrm{~cm}^{2} \mathrm{AAM}$

The performance of the electrochemical reactor leading to the production of large area $25 \mathrm{~cm}^{2}$ AAMs, has been studied under different experimental conditions. The anodizing conditions for the preparation of AAMs with similar features to the commercial ones have been reported in a previous work [27]. Briefly, the electrolyte consists of refrigerated $0.4 \mathrm{M} \mathrm{H}_{3} \mathrm{PO}_{4}\left(\mathrm{~V}^{2} 2 \mathrm{dm}^{3}, 0^{\circ} \mathrm{C}\right)$ and the applied cell voltage has been selected at the value of $150 \mathrm{~V}$. In order to apply such high voltages, particular attention in the design of the reactor has been paid to the hydrodynamic regime of the electrolyte. Under high voltage anodizing conditions local burning has been often observed in slightly stirred and/or high temperatures electrolytes [28,29]. Very high temperatures can be 
reached at the aluminium/solution interface during anodization with respect to the bulk of the electrolyte, due to highly exothermic oxidation and Joule heating of both the solution and the oxide. Due to the high oxide resistance, the Joule heating of the oxide represents the predominant term which can be removed by heat transfer in the electrolytic bath through the control of the hydrodynamic flow pattern of the solution and the decrease of the solution temperature. In the batch reactor the heat removal has been optimised by means of a refrigerant flowing in a silicone serpentine directly immersed in the electrolyte and a vigorous magnetic stirring [30].

In order to avoid drastic increase of temperature, the final tension has been gradually reached by linear potential sweep at $0.2 \mathrm{~V} \mathrm{~s}^{-1}$ [27], as shown in Figure 3a. After the initial current increase the curves present a plateau, during which the growth of an aluminium oxide barrier film, more or less hydrated, occurs. The applied potential was stopped at $150 \mathrm{~V}$ and this value was held for different times in order to produce different oxide thickness. The current vs. time curve at constant cell potential of $150 \mathrm{~V}$ illustrated in Figure $3 \mathrm{~b}$ reproduces the classical behaviour of porous anodic film growth on aluminium [31]. After an initial transient, the current attains a steady-state value where the rate of the field-enhanced dissolution of alumina at the base of the pores equals the oxide formation rate at the metal-oxide interface. Figure $3 \mathrm{c}$ shows that the thickness of the porous layer (measured by SEM) increases with circulated charge as expected for the anodic growth of porous layer [31]. We have to mention that the fabrication of thinner (100-500 nm thick) anodic alumina membranes has been successfully realized by other research groups [32,33]), even if such porous layers resulted o be not self standing.

(a)

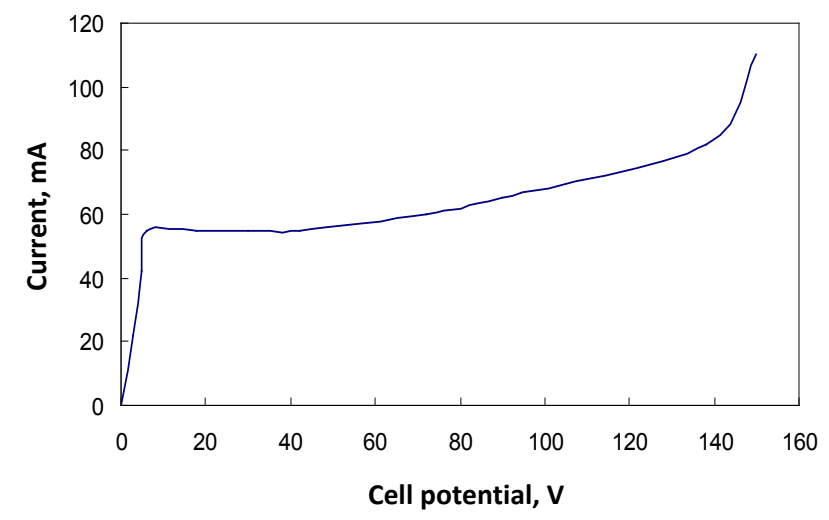

(b)

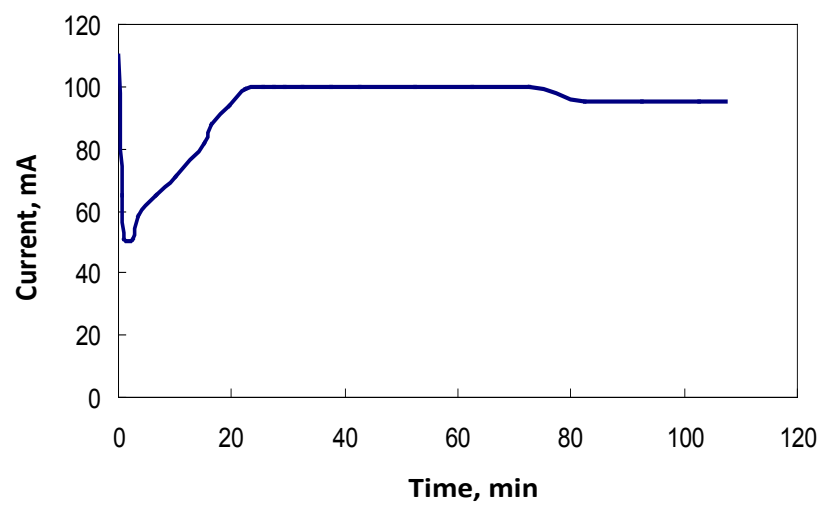

(c)

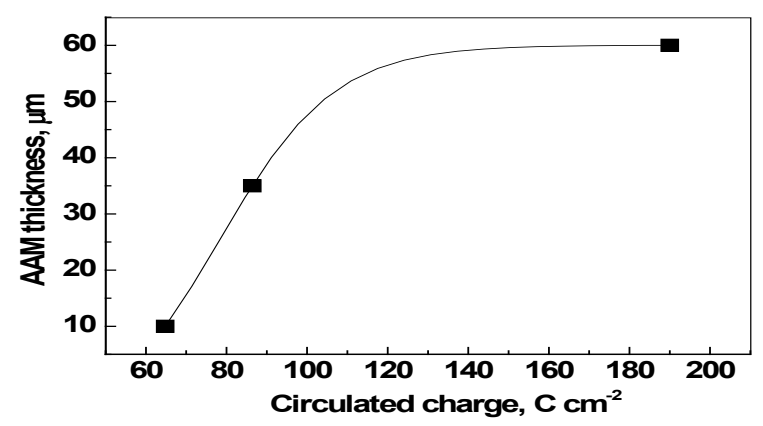

Figure 2: (a) Growth of an anodic oxide film on laminated aluminium using a linear potential scan at $0.2 \mathrm{~V} \mathrm{~s}^{-1}$ in $0.4 \mathrm{M}$ in $\mathrm{H}_{3} \mathrm{PO}_{4}$ at $\mathrm{T}=0{ }^{\circ} \mathrm{C}$ up to $150 \mathrm{~V}$. (b) Current vs. time curves during the growth of an anodic porous layer on laminated aluminium at $\mathrm{U}_{\text {app }}=150 \mathrm{~V}$ in $0.4 \mathrm{M} \mathrm{H}_{3} \mathrm{PO}$ at $\mathrm{T}=0{ }^{\circ} \mathrm{C}$. (c) Thickness of $25 \mathrm{~cm}^{2}$ alumina membranes, fabricated at $\mathrm{U}_{\text {app }}=150 \mathrm{~V}$ in $0.4 \mathrm{M} \mathrm{H}_{3} \mathrm{PO}_{4}$ at $\mathrm{T}=0{ }^{\circ} \mathrm{C}$ as a function of the electric charge

The procedure used to separate the porous film from the aluminium after anodization has been optimized in order to produce self-supported membranes. The residual metal has been dissolved in a vessel similar to the anodizing cell through a window and a gaskets system that expose to the $\mathrm{CuCl}_{2} / \mathrm{HCl}$ solution a lower area than the anodized one. In such a way, the metal border around the aluminium oxide guarantees a simple mechanical support of the alumina membranes and an easy handling even with very small thickness (i.e. $10 \mu \mathrm{m}$ ). After this process the Al-supported AAMs appear as shown in Figure 1, Panel b.

A $50 \mathrm{~cm}^{2}$ AAM reactor has been also constructed by scaling-up the $25 \mathrm{~cm}^{2}$ anodizing cell. Owing to the large electrode area and the volume of solution employed $\left(\mathrm{V}=10 \mathrm{dm}^{3}\right)$, the heat management is more difficult and experiments performed at $150 \mathrm{~V}$ with $0.4 \mathrm{M} \mathrm{H}_{3} \mathrm{PO}_{4}$ show recurrent oxide breakdown. At the same conditions of anodization voltage $(150 \mathrm{~V})$ and temperature $\left(10{ }^{\circ} \mathrm{C}\right)$, by decreasing the acid concentration from 0.4 to $0.1 \mathrm{M}$, the current decreases from 280 to $100-130 \mathrm{~mA}$ allowing long anodization times up to $24 \mathrm{~h}$ without burning, whereas for the $0.4 \mathrm{M}$ acid burning occurred soon after 1 min of anodization. 


\section{Characterization of $25 \mathrm{~cm}^{2}$ AAM}

The SEM morphologies of the solution-side and cross section of anodic membranes grown on as supplied $\mathrm{Al}^{\text {in } 0.4 \mathrm{M} \mathrm{H}_{3} \mathrm{PO}}$ at $5{ }^{\circ} \mathrm{C}$ show that the pores are preferential distributed along the lamination lines of the $\mathrm{Al}$ substrate with a poor order level and scarce circularity (Figure 1a,b,Supporting Information), as previously observed for low areas samples [34]. The oxide layer is more disordered on the solution-side because the alumina porous film reproduces the surface imperfections of $\mathrm{Al}$ in the first times of anodizing and then it grows according a self-ordering process leading to more ordered structure on the metal-side (Figure $1 \mathrm{~d}$,Supporting Information). The pore average diameter of AAM solution-side surfaces has been measured by SEM analysis to be around $130 \mathrm{~nm}$, which is lower than the expected of $200 \mathrm{~nm}[31]$.

The porous film grown in $0.4 \mathrm{M} \mathrm{H}_{3} \mathrm{PO}_{4}$ at applied voltage of $150 \mathrm{~V}$ has been chemically etched in order to dissolve the barrier layer (metal-side) creating an open pore structure and to remove the solution-side disordered porous layer. The influence of chemical etching bath on the front and back morphologies of the membranes has been initially studied by dipping the whole sample in both acidic or alkaline solutions under vigorous stirring. The use of phosphoric acid leads to a non-uniform dissolution of the barrier layer, with the presences of closed-pores areas (Figure 2a, Supporting Information) near to perfectly open-pores areas (Figure $2 \mathrm{~b}$, Supporting Information). On the contrary, the etching of the front layer allows to remove the disordered porous layer with subsequent pore opening effect leading to diameters of $\sim 200 \mathrm{~nm}$ (Figure 2c, Supporting Information).
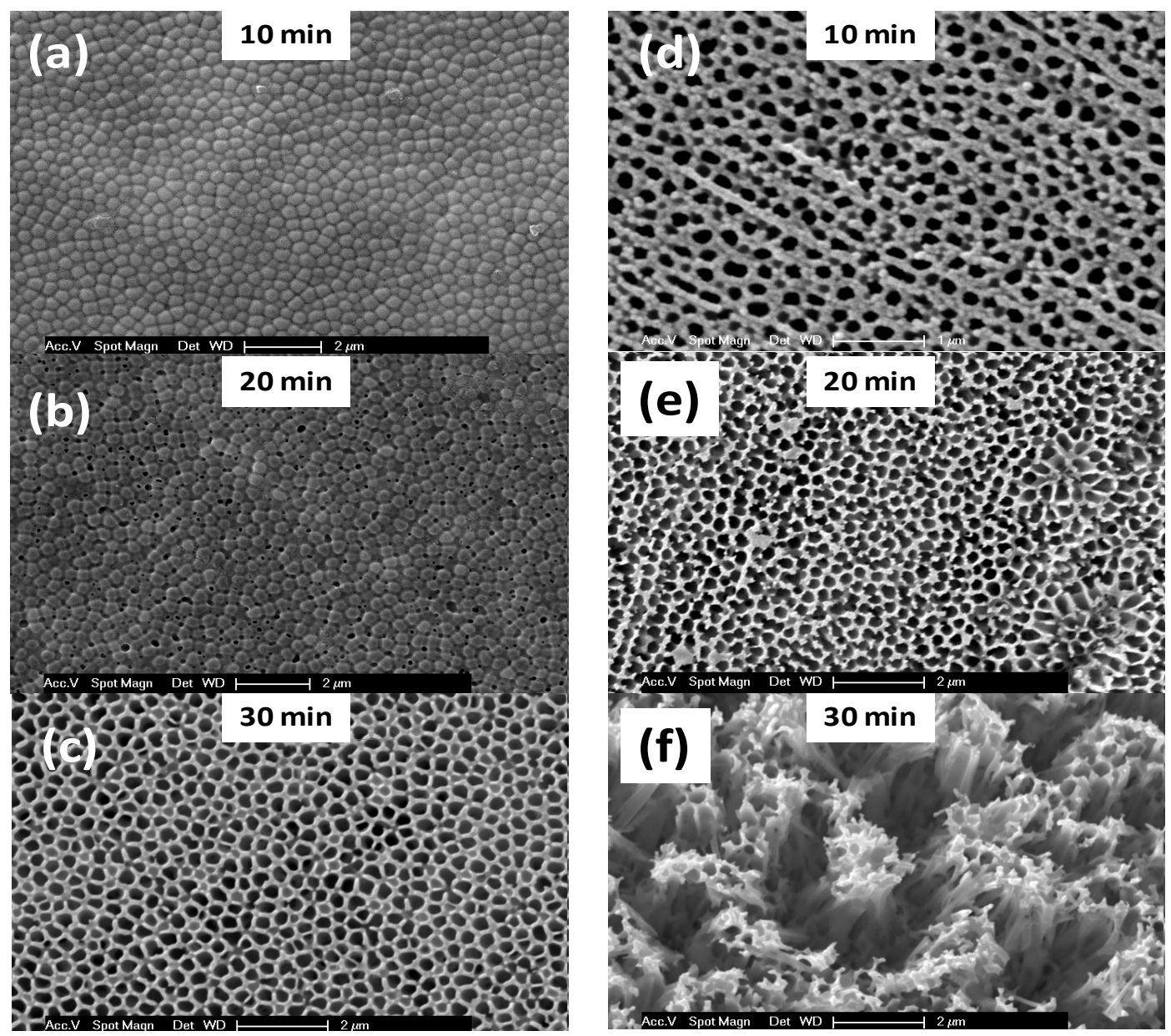

Figure 3: Morphology of the metal side $(\mathrm{a}, \mathrm{b}, \mathrm{c})$ and solution-side $(\mathrm{d}, \mathrm{e}, \mathrm{f})$ surfaces of $25 \mathrm{~cm}^{2} \mathrm{AAM}_{\mathrm{AMepared}}$ in $0.4 \mathrm{M} \mathrm{H}_{3} \mathrm{PO}_{4}$, $150 \mathrm{~V}, 0{ }^{\circ} \mathrm{C}, \mathrm{dU} / \mathrm{dt}=200 \mathrm{mV} / \mathrm{sec}$ after etching in $0.1 \mathrm{M} \mathrm{NaOH}$ for different times

In order to favour a more uniform dissolution of alumina film [35], etching experiments in alkaline aqueous solutions (0.1 $\mathrm{M}$ $\mathrm{NaOH}$ ) have been also performed. In the SEM micrographs of Figure 3a, b, c the influence of the etching time on the metal-side (barrier layer) morphology of the AAM is shown. The barrier layer completely dissolves after 30 min and the analysis performed in different areas of the sample indicates that the pores have been uniformly opened. Looking at the morphologies of the AAM front surfaces (Figure 3d,e,f), it comes out that a long etching time $(30 \mathrm{~min}$ ) causes the collapse of the alumina porous structure (Figure 3f), while a brief etching time (10 min) leads to a good morphology (Figure 3d). These results indicate that AAM can be obtained from the corresponding porous layer by performing chemical treatments in $0.1 \mathrm{M} \mathrm{NaOH}$ for 10 min on the front (solution-side) and $30 \mathrm{~min}$ on the back (metal-side). With this procedure the morphologies of large area AAM look like those relative to $0.2 \mu \mathrm{m}-$ Whatman Anodisk [36]. 
The porous structure of the AAM samples has been also studied by $\mathrm{Hg}$ porosimetry. This technique can determine pore size distributions very precisely. In spite of the simple and low cost fabrication process, which excludes the usual initial steps related to the metal surface treatments (such as electropolishing), the features of $25 \mathrm{~cm}^{2}$ home-made membranes results not so far from to the industrial ones, as summarized in Table 1. In Figure $4 \mathrm{a}, \mathrm{b}$ the $\mathrm{Hg}$ intrusion curves and pore diameters distribution are compared for commercial $\left(0.2 \mu \mathrm{m}\right.$-Whatman) and $25 \mathrm{~cm}^{2}$ home-made membranes before and after chemical etching in $0.1 \mathrm{M}$ $\mathrm{NaOH}$. From the Figure $4 \mathrm{~b}$ it can be observed that the home-prepared AAMs show a bimodal pore size distribution owing to the poor order of the porous structure on the anodizing front. This effect has been corrected by chemical etching of the solution-side disordered surface layer, as shown in the same figure, where the etched AAM samples reach similar features to those of commercial membranes.

\begin{tabular}{|c|c|c|c|}
\hline AAM & Whatman Anodisk $\mathbf{0 . 2} \boldsymbol{\mu \mathbf { m }}$ & $\mathbf{2 5} \mathbf{~ c m}^{\mathbf{2}}$ home-prepared after Al moval & $\mathbf{2 5} \mathbf{~ c m}^{\mathbf{2}}$ home-prepared after chemical etching \\
\hline Total cumulative volume $(\mathrm{cc} / \mathrm{g})$ & 0.485 & 0.312 & 0.574 \\
\hline Total specific surface $\left(\mathrm{m}^{2} / \mathrm{g}\right)$ & 27.17 & 36.09 & 31.63 \\
\hline Average pore diameter $(\mathrm{nm})$ & 252 & 246 & 306 \\
\hline
\end{tabular}

Table 1: Hg porosimetry results for commercial and home-prepared $25 \mathrm{~cm}^{2}$ AAMs.

(a)

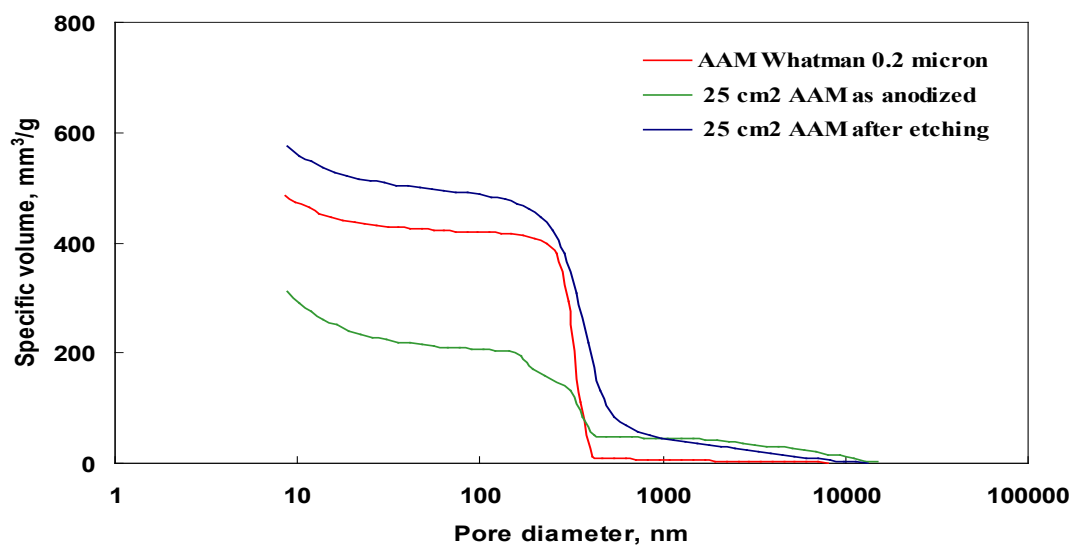

(b)

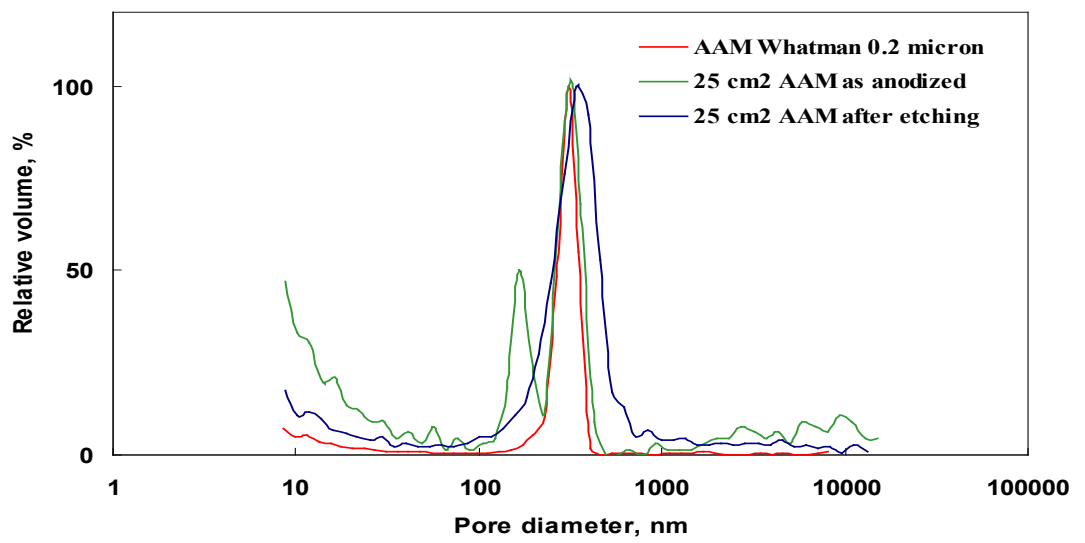

Figure 4: (a) Hg intrusion curves and (b) pore diameter distribution for three different samples: commercial Whatman 0.2 $\mu$ m AAM, homeprepared $25 \mathrm{~cm}^{2}$ AAM before and after etching treatment in $0.1 \mathrm{M} \mathrm{NaOH}$ for $30 \mathrm{~min}$ in the back and $10 \mathrm{~min}$ in the front

\section{Application of $25 \mathrm{~cm}^{2}$ AAM as support of proton conductors in fuel cell}

The large area home-made AAM synthesized in the $25 \mathrm{~cm}^{2}$ batch reactor and submitted to detachment and etching processes have been functionalized with $\mathrm{CsH}_{2} \mathrm{PO}_{4}$ and CSNST proton conductors and tested as electrolyte in a $10 \mathrm{~cm}^{2}$ or $25 \mathrm{~cm}^{2} \mathrm{H}_{2} / \mathrm{O}_{2}$ single module fuel cell. The results will be compared with those of previous papers $[10,12]$ where commercial AAMs $(0.2 \mu$ mWhatman Anodisk) filled with the same proton conductors has been already characterized in the same fuel cell, at a cell and gases temperature of $25^{\circ} \mathrm{C}$ and $1 \mathrm{mg} \mathrm{cm}{ }^{-2}$ Pt loading. Numerous assemblies have been performed in order to optimize the preparation procedure and filling technique of the home-made AAM with the salts.

The initial measurements have been addressed to evaluate the influence of the AAM etching time and thickness on the power output of the fuel cell working with $\mathrm{AAM} / \mathrm{CsH}_{2} \mathrm{PO}_{4}$ electrolyte. The AAMs were prepared in the $25 \mathrm{~cm}^{2}$ reactor and assembled in a $10 \mathrm{~cm}^{2}$ fuel cell. 
The kind of solution used during the barrier layer removal process affects the resulting fuel cell performances. If the porous alumina layer is treated with $0.4 \mathrm{H}_{3} \mathrm{PO}_{4}$ for $4 \mathrm{~h}$, the $\mathrm{AAM} / \mathrm{CsH}_{2} \mathrm{PO}_{4} 10 \mathrm{~cm}^{2}$ fuel cell show typical open circuit voltages (OCV) around $0.8 \mathrm{~V}$ and power output strictly depending on the AAM thickness. Decreasing the AAM thickness from $45 \mu \mathrm{m}$ to $15 \mu \mathrm{m}$, the short circuit current increases from 15 to $55 \mathrm{~mA} \mathrm{~cm}^{-2}$ and output peak power increases from 1.4 to $10 \mathrm{~mW} \mathrm{~cm}^{-2}$ (Figure 5, Panel a). The power output of the home-made $45 \mu \mathrm{m}$ AAM is lower than the commercial $50 \mu \mathrm{m}$ AAM fuel cell for which the average maximum power output is $15 \mathrm{mWcm}^{-2}$ [10]. The main cause can be traced to the only partially dissolved barrier layer which decreases the active area for the proton transport. These results have shown that, owing to the fuel cell kinetic mainly controlled by the ohmic drop in the electrolyte, the power output can be increased by thinning the AAM composite membranes.

(a)

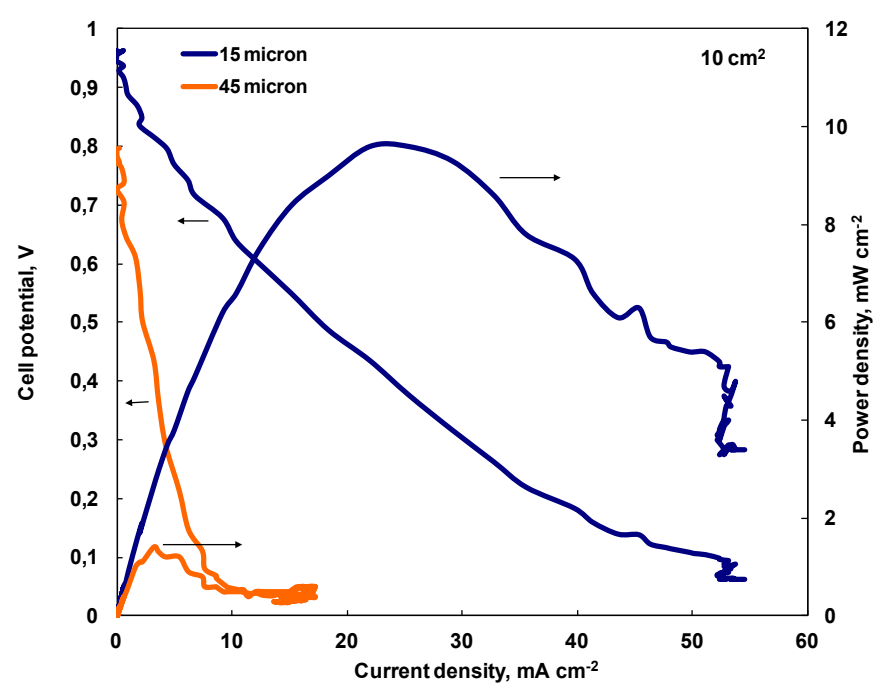

(b)

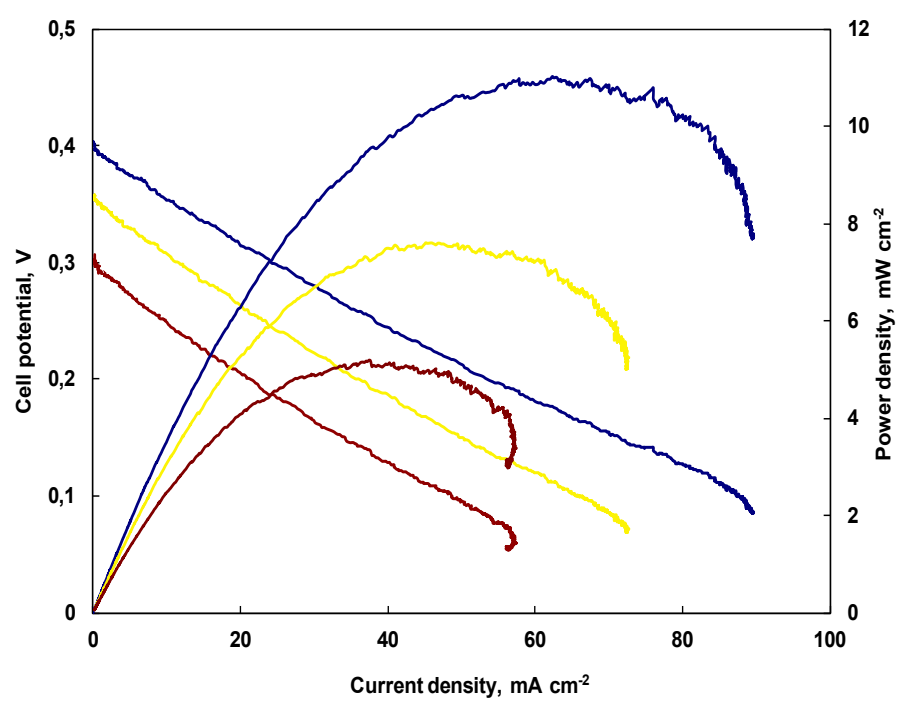

Figure 5: Best polarization curve and power density for $10 \mathrm{~cm}^{2}$ humidified $\mathrm{H}_{2} / \mathrm{O}_{2}$ fuel cell at cell and gas temperatures of $25^{\circ} \mathrm{C}$ working with $1 \mathrm{mg} / \mathrm{cm}^{2} \mathrm{Pt}$ loading and $\mathrm{AAM} / \mathrm{CsH}_{2} \mathrm{PO}_{4}$ composite membranes. The AAM support is home prepared using the $25 \mathrm{~cm}^{2}$ reactor, $0.4 \mathrm{M} \mathrm{H}_{3} \mathrm{PO}_{4}$ electrolyte, applied cell voltage of $150 \mathrm{~V}$. (a) AAM etched in $0.4 \mathrm{M} \mathrm{H}_{3} \mathrm{PO}_{4}$ for $4 \mathrm{~h}(15,45 \mu \mathrm{m})$. (b) AAM etched in $0.1 \mathrm{M} \mathrm{NaOH}$ for $30 \mathrm{~min}$ on both sides (15 $\left.\mu \mathrm{m}\right)$

As shown in Table 2, the performance (evaluated in terms of short circuit current, open circuit potential and peak power) of noncommercial AAM/CsH $\mathrm{PO}_{4} 10 \mathrm{~cm}^{2}$ fuel cell has been also studied as a function of the etching time of the AAM in $0.1 \mathrm{M} \mathrm{NaOH}$ as well as of the AAM thickness (i.e. anodizing circulated charge). As general trend, the performance increases for home-made AAM submitted to longer etching times and decrease with increase of the membranes thickness. For etching times of 30 min, which means complete open-pore structures, and $45 \mu \mathrm{m}$ thickness the first polarization curve is similar to the fuel cell average results obtained with $50 \mu \mathrm{m}$ thick commercial AAMs [10] (OCV=0.8 V, i $\left.\mathrm{sc}_{\mathrm{sc}}=80 \mathrm{~mA} \mathrm{~cm}^{-2}, \mathrm{P}_{\max }=15 \mathrm{~mW} \mathrm{~cm}^{-2}\right)$. Anyway, the power output reveals a scarce stability to cell voltage cycling, probably related to the collapsed morphology of the front AAM surfaces obtained after 30 min of chemical etching (see Figure 3, Panel f).

In Figure 5, Panel b the best fuel cell performance relative to home-made $15 \mu \mathrm{m}$ thick AAMs etched for 30 min (metal and solutionsides) in $0.1 \mathrm{M} \mathrm{NaOH}$ and filled with $\mathrm{CsH}_{2} \mathrm{PO}_{4}$ is reported. The cell voltage cycling influences not only the deliverable current but also the open circuit voltage value. Since the polarization curves maintain the same slope during cycling, the degradation process mainly influences the OCV probably owing to an increased gas crossover inside the membrane. The OCV (0.4 V) of the first curve is drastically lower than that typically measured with commercial AAMs filled with $\mathrm{CsH}_{2} \mathrm{PO}_{4}(0.8 \mathrm{~V})$.

The home-made $25 \mathrm{~cm}^{2}$ AAMs have been also filled with CSNST and assembled in both 10 and $25 \mathrm{~cm}^{2} \mathrm{H}_{2} / \mathrm{O}_{2}$ fuel cell. The recorded polarization curves are shown in Figure 7. The deliverable peak power and maximum current of $10 \mathrm{~cm}^{2}$ fuel cell are in agreement with previous results obtained with commercial AAM filled with the same salt [12]. The power output increases with the increase of the area by a factor of three going from 100 to $300 \mathrm{~mW}$, indicating that the scale-up of the anodizing process can be successfully used to produce AAMs with properties comparable to commercial AAM.

In Figure 6 the polarization curves of a fuel cell assembled with $45 \mu \mathrm{m}$ home-made AAM subjected to different etching times on the front $(10 \mathrm{~min})$ and the back $(30 \mathrm{~min})$ and then filled with $\mathrm{CsH}_{2} \mathrm{PO}_{4}$ are shown. The differential etching treatments of the porous layers, owing to a better solution-side morphology, lead to fuel cell performance comparable with those obtained with commercial AAM membranes. As discussed in [10] for commercial AAM/CsH $\mathrm{PO}_{4}$ assemblies, the fuel cell power loss with potential cycling can be associated to possible dissolution effect of the proton conductor due to an excess of water into the cathodic flow pattern. 


\begin{tabular}{|c|c|c|c|}
\hline $25 \mathrm{~cm}^{2}$ AAM thickness $(\mu \mathrm{m})$ & OCV $(\mathrm{V})$ & $I_{s c}\left(\mathrm{~mA} \mathrm{~cm}^{-2}\right)$ & $P_{\max }\left(\mathrm{mW} \mathrm{cm}^{-2}\right)$ \\
\hline \multicolumn{4}{|c|}{ Etching time $=10 \mathrm{~min}$} \\
\hline 15 & 0.5 & 22 & 2.5 \\
\hline 30 & 0.79 & 9 & 1.6 \\
\hline 45 & 0.7 & 1.5 & 0.2 \\
\hline \multicolumn{4}{|c|}{ Etching time $=20 \mathrm{~min}$} \\
\hline 15 & 0.73 & 65 & 11 \\
\hline 30 & 0.8 & 20 & 3 \\
\hline 45 & 0.71 & 20 & 2.6 \\
\hline \multicolumn{4}{|c|}{ Etching time $=30 \mathrm{~min}$} \\
\hline 15 & 0.4 & 90 & 11 \\
\hline 45 & 0.7 & 75 & 10.7 \\
\hline
\end{tabular}

Table 2: Performance of $10 \mathrm{~cm}^{2} \mathrm{H}_{2} / \mathrm{O}_{2}$ fuel cell with composite AAM/CsH $\mathrm{PO}_{4}$ membranes prepared from $25 \mathrm{~cm}^{2}$ AAM after etching in $\mathrm{NaOH} 0.1 \mathrm{M}$ for different times reported as a function of the AAM thickness. (Isc=short circuit current)

(a)

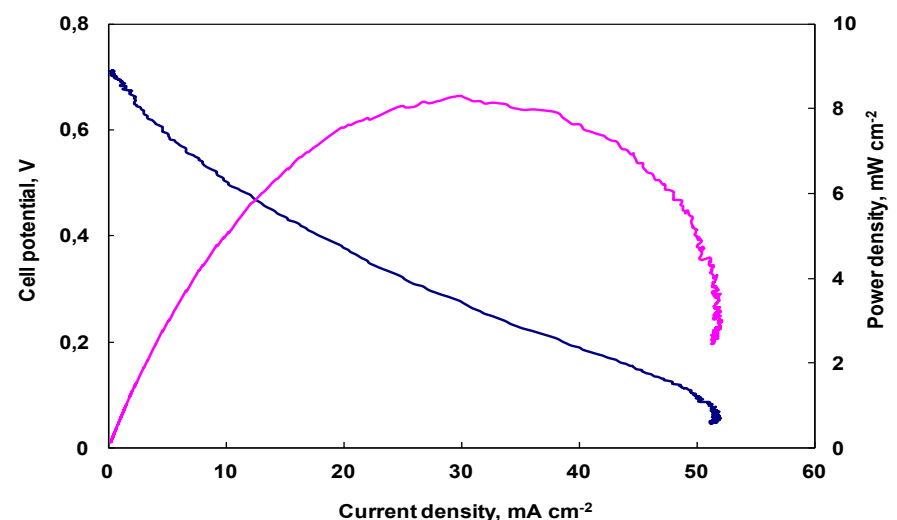

(b)

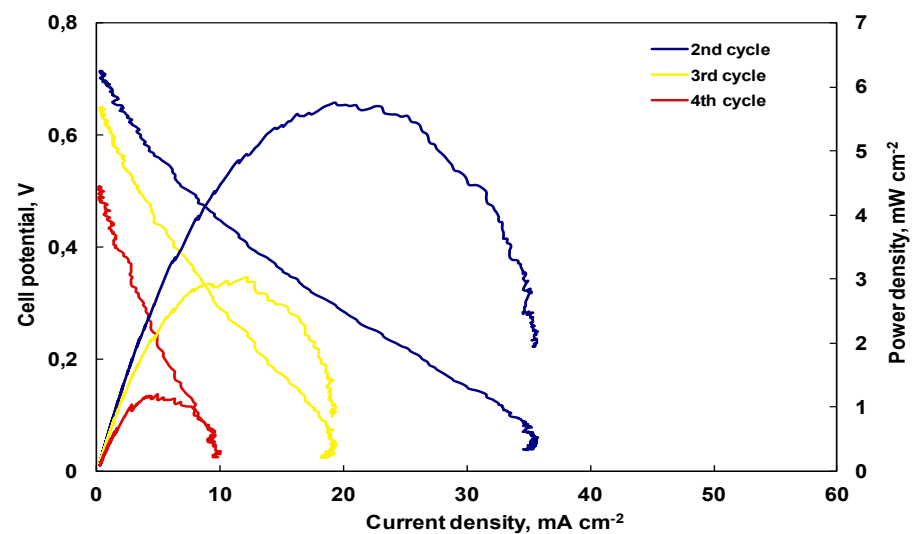

Figure 6: Best polarization curve and power density for $10 \mathrm{~cm}^{2}$ humidified $\mathrm{H}_{2} / \mathrm{O}_{2}$ fuel cell at cell and gas temperatures of $25^{\circ} \mathrm{C}$ working with $1 \mathrm{mg} / \mathrm{cm}^{2} \mathrm{Pt}$ loading and $\mathrm{AAM} / \mathrm{CsH}_{2} \mathrm{PO}_{4}$ composite membranes. The AAM support is home prepared using the $25 \mathrm{~cm}^{2}$ reactor, $0.4 \mathrm{M} \mathrm{H}_{3} \mathrm{PO}_{4}$ electrolyte, applied cell voltage of $150 \mathrm{~V}$ and etched in $0.1 \mathrm{M} \mathrm{NaOH}$ for $30 \mathrm{~min}$ in the back and $10 \mathrm{~min}$ in the front. a) first cycle, b) successive cycles 


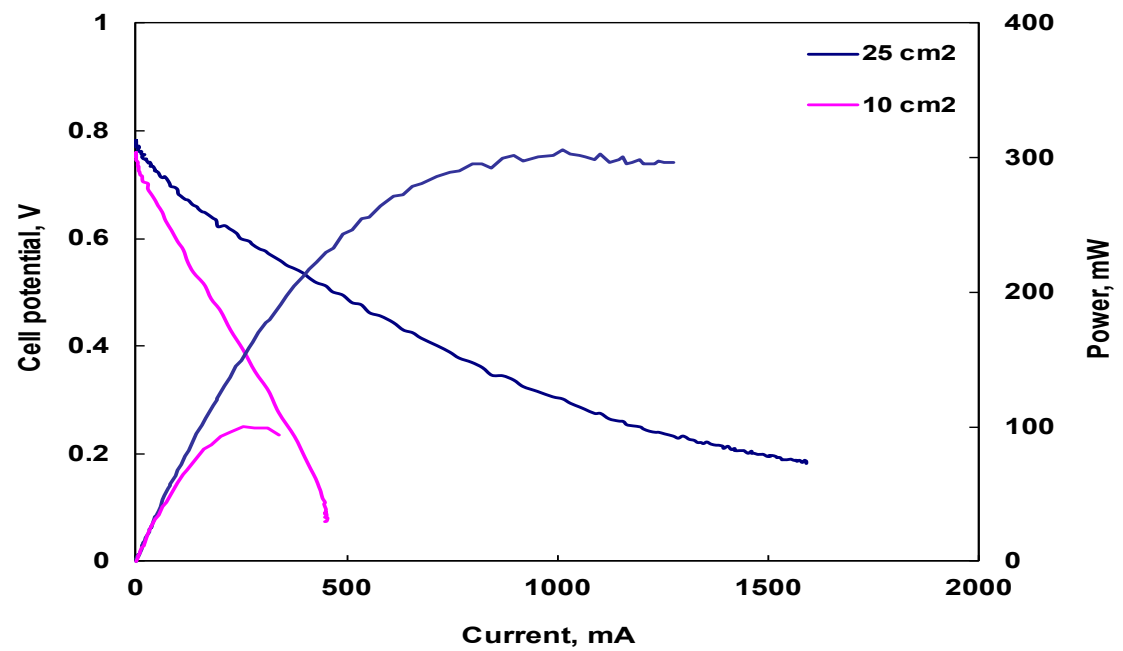

Figure 7: Best polarization curve and power density for $10 \mathrm{~cm}^{2}$ and $25 \mathrm{~cm}^{2}$ humidified $\mathrm{H}_{2} / \mathrm{O}_{2}$ fuel cell at cell and gas temperatures of $25{ }^{\circ} \mathrm{C}$ working with $1 \mathrm{mg} / \mathrm{cm}^{2} \mathrm{Pt}$ loading and AAM/CsNST composite membranes. The AAM support is home prepared using the $25 \mathrm{~cm}^{2}$ reactor, $0.4 \mathrm{M} \mathrm{H}_{3} \mathrm{PO}_{4}$ electrolyte, applied cell voltage of $150 \mathrm{~V}$ and etched in $0.1 \mathrm{M} \mathrm{NaOH}$ for $30 \mathrm{~min}$ in the back and $10 \mathrm{~min}$ in the front

\section{Conclusion}

In this work, we have described the design of an electrochemical reactor for the fabrication of self-supported comparatively thin (up to $10 \mu \mathrm{m}$ ) and large area (up to $50 \mathrm{~cm}^{2}$ ) AAMs, explaining in detail how to solve the typical experimental difficulties related to the anodization of large area electrodes. A metal border is left around the anodized aluminium in order to create a simple mechanical support of the alumina membranes with an easy handling up to 10 micron. The etching of the barrier layer has been optimized by choosing the relevant conditions giving uniform and complete pore opening. The anodizing cell leads to the production of 25 and $50 \mathrm{~cm}^{2}$ AAMs with similar characteristic to the commercial anodisk (pore diameters $200 \mathrm{~nm}$ and pore densities $1012 \mathrm{pores} / \mathrm{m}^{2}$ ), as proved by SEM morphological analysis and Hg-porosity measurements. After filling with proton conductors, the performance and the scalability of large area home-made AAM assembled into 10 and $25 \mathrm{~cm}^{2} \mathrm{H}_{2} / \mathrm{O}_{2}$ fuel cell demonstrate their successful application to technological devices of actual interest.

\section{Acknowledgements}

We gratefully thank Giuseppe Fanale for the indispensable technical support to the realization of the anodization cell. We are also indebted with Dr Francesca Conciauro and Ing. Fabio D’Agostino for their high qualified contribute to fuel cell and Hg-porosity measurements, respectively.

\section{Click here to download Supporting Figures}

\section{References}

1. Hoyer P, Masuda H (1996) Electrodeposited nanoporous $\mathrm{TiO}_{2}$ film by a two-step replication process from anodic porous alumina. J Mater Sci Lett 15: 1228-30.

2. Ishikawa Y, Matsumoto Y (2001) Electrodeposition of $\mathrm{TiO}_{2}$ photocatalyst into nano-pores of hard alumite. Electrochim Acta 46: 2819-24.

3. Bocchetta P, Santamaria M, Di Quarto F (2008) Cerium Oxyhydroxide Nanowire Growth via Electrogeneration of Base in Nonaqueous Electrolytes. Electrochem Solid-State Lett 11: K93-7.

4. Bocchetta P, Santamaria M, Di Quarto F (2009) From ceria nanotubes to nanowires through electrogeneration of base. Journal of Applied Electrochem 39: 2073-81.

5. Bocchetta P, Santamaria M, Di Quarto F (2008) Electrosynthesis of Ce-Co Mixed Oxide Nanotubes with High Aspect Ratio and Tunable Composition. Electrochem. Solid-State Lett 11: K27-30

6. Cheng GS, Chen SH, Zhu XG, Mao YQ, Zhang LD (2000) Highly ordered nanostructures of single crystalline GaN nanowires in anodic alumina membranes. Mater Sci Eng A286: 165-8.

7. Seo DS, Lee JK, Kim H (2001) Preparation of nanotube-shaped $\mathrm{TiO}_{2}$ powder. J Crystal Growth 229: 428-32.

8. Zhang J, Kielbasa JK, Carroll DL (2010) Controllable fabrication of porous alumina templates for nanostructures synthesis. Mater Chem Phys 122: 295-300.

9. Bocchetta P, Chiavarotti GP, Masi R, Sunseri C, Di Quarto F (2004) Nanoporous alumina membranes filled with solid acid for thin film fuel cell at intermediate temperatures. Electrochem Comm 6: 923-8.

10. Bocchetta P, Ferraro R, Di Quarto F (2009) Advances in Anodic Alumina Membranes-based fuel cell: $\mathrm{CsH}_{2} \mathrm{PO}_{4}$ pore-filler as proton conductor at room temperature. Journal of Power Source 187: 49-56.

11. Bocchetta P, Conciauro F, Di Quarto F (2007) Nanoscale membrane electrode assemblies based on porous anodic alumina for hydrogen-oxygen fuel cell. Journal of Solid State Electrochemistry 11: 1253-61.

12. Bocchetta P, Conciauro F, Santamaria M, Di Quarto $\mathrm{F}(2011) \mathrm{Cs}_{0.86}\left(\mathrm{NH}_{4}\right)_{1.14} \mathrm{SO}_{4} \mathrm{Te}(\mathrm{OH})_{6}$ in porous anodic alumina for micro fuel cell applications. Electrochim Acta 56: 3845-51. 
13. Thompson GE, Furneaux RC, Wood GC, Richardson JA, Gode JS (1978) Nucleation and growth of porous anodic films on aluminium. Nature 272: 433-5.

14. Thompson GE, Wood G (1981) Porous anodic film formation on aluminum. Nature 290: 230-2.

15. Furneaux RC, Rigby WC, Davidson AP (1989) The formation of controlled-porosity membranes from anodically oxidized aluminum. Nature 337: 147-9.

16. Martin J, Manzano CV, Caballero-Calero O, Martin-Gonzalez M (2013) High-aspect-ratio and highly ordered 15-nm porous alumina templates. ACS Appl Mater Inter 5: 72-9.

17. Hebert KR, Albu SP, Paramasivam I, Schmuki P (2012) Morphological instability leading to formation of porous anodic oxide films. Nature Materials 11: $162-6$.

18. Nishinaga O, Kikuchi T, Natsui S, Suzuki RO (2013) Rapid fabrication of self-ordered porous alumina with 10-/sub-10-nm-scale nanostructures by selenic acid anodizing. Scientific Reports 3: Article number: 2748.

19. Nielsch K, Muller F, Li AP, Gosele U (2000) Uniform Nickel Deposition into Ordered Alumina Pores by Pulsed Electrodeposition. Adv Mater 12: 582-6.

20. Rauf A, Mehmood M, Asim Rasheed M, Aslam M (2009) The effects of electropolishing on the nanochannel ordering of the porous anodic alumina prepared in oxalic acid. J Solid State Electrochem 13: 321-32.

21. Chu SZ, Wada K, Inoue S, Todoroki S (2003) Fabrication and characteristics of nanostructures on glass by Al anodization and electrodeposition. Electrochim Acta 48: 3147-53.

22. Bocchetta P, Sunseri C, Bottino A, Capannelli G, Chiavarotti G, et al. (2002) Asymmetric alumina membranes electrochemically formed in oxalic acid solution. Journal of Applied Electrochem 32: 977-85.

23. Li AP, Müller F, Birner A, Nielsch K, Gösele U (1998) Hexagonal pore arrays with a 50-420 nm interpore distance formed by self-organization in anodic alumina. J Appl Phys 84: 6023-6.

24. Masuda H, Satoh M (1996) Fabrication of gold nanodot array using anodic porous alumina as an evaporation mask. Jpn J Appl Phys 35: L126-9.

25. Ono S, Saito M, Asoh H (2004) Self-Ordering of Anodic Porous Alumina Induced by Local Current Concentration: Burning. Electrochem Solid State Lett 8: B21-4.

26. Schneider J, Engstler J, Budna KP, Teichert C, Franzka S (2005) Freestanding, Highly Flexible, Large Area, Nanoporous Alumina Membranes with Complete Through-Hole Pore Morphology. Eur J Inorg Chem 2005: 2352-9.

27. Bocchetta P, Sunseri C, Chiavarotti G, Di Quarto F (2003) Microporous alumina membranes electrochemically grown. Electrochim Acta $48: 3175-83$.

28. De Graeve I, Terryn H, Thompson GE (2003) Influence of Local Heat Development on Film Thickness for Anodizing Aluminum in Sulfuric Acid. Journal of Electrochem Soc 150: B158-65.

29. De Graeve I, Terryn H, Thompson GE (2002) Influence of heat transfer on anodic oxidation of aluminium. Journal of Applied Electrochem 32 : 73-83.

30. Stępniowski WJ, Norek M, Michalska-Domańska M, Bojar Z (2013) Ultra-small nanopores obtained by self-organized anodization of aluminum in oxalic acid at low voltages. Mat Lett 111: 20-3.

31. Diggle JW, Downie TC, Goulding CW (1969) Anodic oxide films on aluminum. Chem Rev 69: 365-405.

32. Kokonoua M, Giannakopoulosb KP, Nassiopouloua AG (2007) Few nanometer thick anodic porous alumina films on silicon with high density of vertical pores. Thin Solid Films 515: 3602-6.

33. Toccafondi C, Stępniowski WJ, Leoncini M, Salerno M (2014) Advanced morphological analysis of patterns of thin anodic porous alumina. Materials Characterization 94: 26-36.

34. Bocchetta P, Sunseri C, Masi R, Piazza S, Di Quarto F (2003) Influence of initial treatments of aluminium on the morphological features of electrochemically formed alumina membranes. Materials Science and Engineering C 23: 1021-6.

35. Compton RG (1989) New techniques for the study of electrodes and their reaction. Green N, Hardbound 10: 427-52.

36. Whatman Anopore. 